\title{
The Urgency of Establishing a Special Unit for Implementing Civil Court Decisions in Order to Improve the Supremacy of Law in Indonesia
}

\author{
Dyah ErsitaYustanti \\ \{dyustanti@yahoo.com\} \\ Universitas 17 Agustus 1945 Jakarta, Jakarta, Indonesia
}

\begin{abstract}
The parties to the litigation need an expectation not only to obtain a verdict on a case submitted, but also need a legal certainty and justice for the dispute. Basically a verdict on civil law is carried out voluntarily by the party who get lost but the implementation can also be requested to the court if the losing party does not deign to implement it voluntarily. The regulatory obstacles, infrastructure and human resources results a delayed execution, incomplete execution or even non- execution effects. These obstacles are very influential in many sectors in Indonesia. The Judicial Independency Study and Advocacy Institute (LiEP), shows that not all of incoming execution requests for civil disputes has been revolved. Thus a new breakthrough that is more effective and efficient is needed through reforming the rules by forming special units as technical implementers in order to resolve existing obstacles to increase the rule of law in Indonesia.
\end{abstract}

Keywords: Civil Execution, And Execution Technical Unit

\section{Introduction}

Court of law plays a significant role in regards to law enforcement in Indonesia. Whenever a dispute take place, it is a place the main medium utilized by people in order to reach desired settlement, beside other familiar means such as mediation and arbitration institution.

Ligitating parties involved expect not only to get a court decision on the dispute submitted, but also legal certainty and justice from the resolution of the dispute. Given the magnitude of the case expenses to be incurred and the length of time required to resolve disputed issues, court results are expected to be in accordance with the restoration of the right to a decision.

Fundamentally, the decision in a civil case is carried out voluntarily by the losing party, but often the volunteerism does not appear as the end of the completion of a court decision.[1] Consequently, court assistance is required to execute the court's decision and restore the rights of justice seekers. [2]

The obstacles faced by the court in carrying out executions ane very much divided among others due to parties involved, such as the resistance requested by the execution, delay, third party resistance, obscurity of the object of execution, peace outside the trial not recorded, the absence and / or unclear rules regarding execution expenses, execution time and aanmaning trial, inspection of goods to be assessed, auction process with its own complexity 
and problems, etc., subsequently also due to internal burden from the Court due to the authority of civil execution, execution of national and intemational arbitration decisions, execution of decisions of the Consumer Dispute Settlement Agency, execution of decisions of the Business Competition Supervis ory Commis sion, execution of Decis ions of the Information Commission, including execution of documents equivalent to decisions such as gross deed, mortgage certificate, and fiduciary guarantee certificate.[3]

\section{Research Purposes}

Research is a tool us ed by humans to strengthen, foster and develop knowledge. So that researchers hope that this research can provide benefits to readers. The benefit of this res earch is to fill the empty spaces of knowledge specifically for the renewal of national law.

\section{Method}

This study us es normative juridical research methods. Normative juridical res earch is legal literature research conducted by examining primary and secondary legal materials using the legislation approach and legal concept analysis approach, made by reviewing all laws and regulations relating to legal is sues. [4]

Normative legal research functions to provide juridical argument when there is gap, obscurity, and norm conflicts. Furthermore, legal research has the role of maintaining critical aspects of legal science as a normative science that is sui generis.[5]

\section{Result and Dis cus sion}

Chairman of the District Court in his position (ex-officio) is an official authorized to lead and execute civil cases. The task carried out by the Chairperson of the Court is ass isted by the Registrar and Bailiff as mandated in Article 54 paragraph (2) of Law 48/2009, and Article 195 paragraph (1) of the HIR or Article 206 paragraph (1) of Rbg.

The practice that occurs in Indonesia, seems more complicated when compared to other countries. For example in Italy, the implementation of court decisions is not carried out by the Chair of the Court, but is carried out by other parties in the intemal court called the Execution Judge whose duty is to examine whether a decision is executed, then issue a pracetto or an order of execution.[6] In Germany, executions are carried out by legal servants (rechspflegers) who are tasked with examining requests, making decisions on requests, issuing writ of execution letters, issuing and signing decisions, issuing enforceable execution copies, and calling the losing party to notify the list of as sets owned.[7]

Different practices occur in the Netherlands, where the execution authority is outside the court, namely by a private party named Koninklijke Beroepsorganisatie van Garechtsdeurwaarders ("KBvG") or The Royal Professional Organization of Judicial Oifficers in The Nederlands, which was formed under the Law on Judicial Officers. The main duties of the Judicial Officer are in principle almost similar to those of the bailiff but with broader authority, including:[8] 
1) Implement court decisions;

2) Make calls on civil matters;

3) Serve requests for legal warnings;

4) Collecting debt froma third party for a legal process;

5) Carry out an inventory of wealth and taxes;

6) Under certain conditions, the authority to make a detention, for example the detention of the respondent who does not pay for child care costs decided by the court;

7) Enter the defendant / debtor's house; and

8) Manage digital records of carrying out its duties and authorities including data and information on all confis cations.

The practice of executions occurring in the countries mentioned above shows that execution does not always become a monopoly of the head of the court, but gives authority to certain officials or specific institutions specifically.

\section{Execution Process}

The petition for execution is submitted by the Petitioner to the Chief of Justice, the Court Chair will instruct the bailiff to make a resume of the request for execution. On that bas is, the Chairperson of the Court will produce a Letter of Determination of the execution followed by a summons to the requesting execution to carry out the execution voluntarily. In accordance with Article 196 of the HIR, upon request for execution, the Chairperson of the Court will order the bailiff to warn the requesting execution so that at the latest 8 (eight) days will voluntarily execute the decision.

Article 197 HIR basically states that if the respondent does not carry out the decision until the end of the aanmaning period, the chairman of the court will issue an order to carry out the execution or also referred to as an execution determination as regulated in the Decree of the Chief Justice of the Supreme Court No. 26 of 2012 conceming Public Service Standards. Execution's implementation including: [9]

1) Information regarding therequest for execution along with supporting evidence;

2) Summary and results of the aanmaning session;

3) The determination of the application for execution; and

4) Command the clerk and / or the auditor to execute.

However, the execution determination does not contain how the execution is carried out, so that the bailiff must think of his own way how to access the executable object, what if the executable object has changed and/or not found, what if the executable object is not enough to fulfill the achievement and so on. Meanwhile, the authority of the bailiff is very limited besides the lack of competent human resources and the provis ions of civil procedural law in Indonesia which are still very behind and not in accordance with current business developments which makes execution difficult to do. At the time of the request for execution was submitted by the execution applicant, the request must be completed with data on the object to be executed, such as the land certificate number and location, bank name and number as well as the account holder's name, stock number, car number plate and other matters. 
Problems arise if it turns out the company did not make and or issue stock certificates. Likewise with the possibility of a land certificate that has been reversed by the name of the executor or the execution has made an agreement with a third party and given a date backwards so as if the object of the execution does not belong to the requesting execution. All of these conditions make the bailiff face problems in carrying out their duties. Because it is different from confiscation in the bankruptcy process, which allows the curator by all means given the authority to recover assets that become bankrupt bankruptcy. In civil execution, the bailiff is only authorized to carry out his duty to execute the object of the dispute that has been stated in the request for execution. In the event of differences in data from the object of execution, the bailiff does not have the authority to conduct further research and pursuit.

When compared with Italy, it is stated that the execution order (pracetto) also includes a description of the actions that can be taken during the execution.[10] Thus, to strengthen the execution, a more detailed explanation is needed on how to implement the decision in ways that are in accordance with the law.

Based on the problems that arise in the implementation of the execution of civil decisions as explained above, a breakthrough is needed in order to create an effective and efficient execution system so as to guarantee legal certainty which will ultimately increase the rule of law in Indonesia.

\section{The Burden of the Chair of the Court}

As explained above, the Chief Justice has a lot of administrative and position burdens in addition to being a judge. These expenses include as officials in the area, attending invitations sent by regional leaders and other invitations. The Chief Justice must also be responsible for the continuity and administration of the district court he presides over. As a judge, the head of the court also becomes a panel of judges who examine criminal and civil cases. The execution was also carried out and led by the Chair of the Court, such as the execution authority in civil cases, execution of national and international arbitration decisions, execution of decisions of the Consumer Dispute Resolution Board, execution of decisions of the Business Competition Supervis ory Commission, execution of Decis ions of the Information Commission, including execution of documents that Equated with decisions such as gross deed, mortgage certificate, and fiduciary guarantee certificate. If there is no res istance and / or problems with the request for execution and / or the object of execution, of course the execution is not complicated, but if there are many problems with the execution process or the object of the dispute, then the burden of the Chief of the Court will increase. In connect ion with that, the authors propose that the execution process, removed from the obligations and authority of the Chair of the Dis trict Court, and formed a special unit that has the authority and obligation to carry out and take care of the execution process of the court's decision.

In addition to internal problems that cause execution to experience obstacles, there are also external problems such as "deception" of the object of execution and / or the ass ets of the respondent in various ways, determining the price of the object of execution, treatment of the object of execution which will ultimately reduce the selling price and many other things. For this reason, it is necessary to change the rules from what has been used as a guide for the execution. 


\section{Position of Special Unit Imple menting the Decision of Civil Matters}

Basically, the Execution is part of the authority of the Chairperson of the District Court assisted by the Registrar and Bailiff as mandated in Article 54 paragraph (2) of Law 48/2009 which says:

" The execution of the court's decision in the civil case was done by the clerk and the deputychaired by the chiefjustice".

Thus, in order to execute the execution, there are 3 authorized authorities among others:

1) Head of Dis trict Court

In the execution of the execution, the authority of the Chair of the District Court is regulated in Article $195 \mathrm{HIR}$ and $206 \mathrm{Rbg}$ viz:

a) Authority to review requests for execution to see whether an execution request can be carried out or not;

b) The authority to order the bailiff to summon the defendant or the request for execution to come to court to be warned to implement the decis ion voluntarily;

c) Authority to give waming (aanmaning) to the respondent to execute the decision voluntarily within a period ofno later than 8 days;

d) The authority to set the execution order as the bas is for executing it and order the clerk and / or arbitrator to carry out the forced execution if within 8 days as referred to in figure 3 is not voluntary; and

e) Authority to oversee the execution of executions (Article 55 of Law 48/2009)

2) Registrar

The role of the Registrar is to ass ist the Chairperson of the District Court when conducting requests for execution and conducting aanmaning, the role is further specified in Article 65 Paragraph (1) of Law No. 2 of 1986 and Article 103 of Law No. 7 of 1989 , i.e.:

a) Execute all orders given by thechairperson;

b) Deliver announcements, reprimands, protests, and notices of court decis ions in ways based on the provisions of the law;

c) Confis cate upon the order of the president of the court;

d) Make news of the seizure event for which the copy has been passed on to the stakeholders.

3) Bailiff

In addition to the Regis trar, the official who helped the Chief Justice to carry out the execution was the bailiff. Elucidation of Article 46 letter e Law No. 48 of 2009 concerning Judicial Power mentions bailiffs as other judicial officials outside the secretary; Vice Secretary; deputy clerks; successor clerks and other s tructural officials. 
SK KMA No. KMA / 055 / BK / X / 1996 conceming the Duties and Respons ibilities and Work Procedures of the Seizure Clerk of the PN and PA states that what is the duty of the bailiff as referred to in Article 5 of SK KMA No. KMA / 055 / BK / X / 1996, i.e.:

a) The Bailiff has a duty to call;

b) Perform the task of carrying out court decisions led by the chairman of the court;

c) Making the minutes of the implementation of the decis ion whos e official copy is conveyed to the parties concerned;

d) Make an offer of money payment; and

e) Make the minutes of offering money payment by stating the amount and description of the types of currencies offered

Whereas the responsibility of the bailiff is regulated in Article 8 of KMA Decree No. KMA/055/ BK/X/1996, i.e.:

a) In the cas e of being appointed to carry out the execution, the bailiff or substitute bailiff is responsible to the head of the court;

b) In carrying out the summons or submission of announcements, reprimands, protests and notices of the bailiff or substitute bailiff is responsible to the head of the court or chair of the hearing; and

c) In the case of confiscation, the surrogate or substitute bailiff is responsible to the head of the court or the chair of the hearing.

Thus, the three officials as mentioned above are the spearhead that has the authority to resolve civil decisions through execution. In addition to the volunteerism of the petitionee for execution, these officials determine the success or failure of the execution.

Considering the problems that have been described previously in the discussion, legal breakthroughs are needed both formally and materially to overcome these problems.

In connection with that, based on this research, the authors provide input to form a special unit that is integral under the position of the Chairperson of the District Court, res ponsible to the Chair of the District Court by taking over part of the authority of the Chair of the Dis trict Court to improve the system of civil court execution more effective and efficient.

The Special Unit was formed from the Panel of Judges who examined and adjudicated cas es where the relevant judge was more aware of the subject matter he had handled. The Executing Judge is assisted by a Substitute Registrar and Bailiff. The official is given an assignment letter or decree by the Chief Justice as the bas is for delegation of authority to act on behalf of the Chief Justice to make efforts in the context of implementing the decision. 
Therefore, changes are needed to the Civil Procedure Law in Article 196 and Article 197 HIR and Article 54 paragraph (2) of Law 48/2004, to then be regulated more technically by / in Supreme Court Regulations.

As explained earlier, as a material comparis on to the practices prevailing in Italy, Germany and the Netherlands which have special units specifically tasked with carrying out decisions. The practice of executions in the countries mentioned above shows that executions are not always a monopoly of the Chair of the Court, but can be given to certain officials or specific institutions specifically.

\section{The Authority Restriction of Special Unit of Civil Laws uit Executor}

According to the writer, the head of the Court carry a heavy burden and responsibility to execute the decision made. Although, they are being helped by the clerk and the bailiff, in order to reach an effective and efficient law system in upholding law supremacy, the authority decentralization is needed

Based on several problems mentioned above, there should be a clear boundary of the authority given to this special unit of civil suit implementation.

According to the writer, there are 5 authorities of special unit of civil lawsuit executor such as:

1) Study case of execution pleading

This special unit have an authority to ass ess execution pleading, the entire files, asses the executorial decision, and provide reprimand letter to execution's defendant to enforce the decision voluntary by still holding on to humanity and justice.

2) Investigation and assessment of seized assets

Special unit has given the authority to investigate and to assess the assets which is going to be seized, give command to public assessor whether or not the good is enough to be seized.

3) Maintenance of execution's seized goods

Special unit release warrant to execution's defendant to maintain the seized goods in order to keep the goods value stable, according to this authority, special unit authorized to do full supervision, if the defendant doesn't implement and put responsibility into it in a proper way, this special unit has full right to move, empty, or keep the seized goods with the expenses are charged to the defendant.

4) Execution Fee

Special unit authorized in determining of execution's fee which need to be paid, including if there is any additional charge.

5) Assets search for executions payment

Special unit authorized in searching the whole assets of execution payment by utilizing civil records, taxes, finance, stocks, including releasing a warrant to 
open, notify, and report the whole information by cooperating with another state council oh which given an authority by the constitution to keep the records. Special unit also authorized in asking information straightly to execution's defendant and assess the validity of the information.

6) The Establishment of Execution

Special unit authorized to publish the establishment of execution, which provide detail's information related to execution's object, how to seek for patronage from the police, and how to seek for maximum information based on legal action's object which sustain the situation for bailiff to execute the execution's object. One of the examples of this applied rules is in applying the principle of actio Pauliana whichenable the bailiff to pursue legalaction's objectmaximally.

\section{Conclusion}

Based on the above description, the conclusion of this article is the implementation of the execution is a part of justice seeker's purpose in defending, protecting and taking their right. Law Process which takes very long time and requires sumptuous charge must equal with the result. It should not inflict a financial loss for them because the execution process was obstructed or even undone. Nowadays, the execution has been delayed for several reasons . Aftermath societies believe in court, law system, and judges descend. The court carry a very heavy burden and responsibility in their daily routine task. Thereupon, the establishment of special unit civil execution is highly necessary. The existence of this special unit is expected to make the execution process is able to be done properly so that those justice seekers are fulfilling their right and law supremacy remain stable.

Hereafter, Special Unit of Execution will have duty and authority such as study case of execution pleading, investigation and assessment of confiscated assets, maintenance of confis cated goods, and as sets search of executions payment.

\section{Reference}

[1] Retnowulan Sutantio dan Iskandar Oeripkartawinata, Hukum Acara dalam Teori dan Praktek, Bandung: Mandar Maju, 1989.

[2] M. Dja'is, Pikiran Dasar Hukum Eksekusi, Semarang: Fakultas Hukum Universitas Diponegoro, 2000.

[3] LeIP (a), Asesmen Awal Permasalahan Eksekusi Putusan Perkara Perdata di Indonesia, Jakarta: Leip, 2018

[4] R. Soerjono Soekanto, Penelitian Hukum Nomatif (Suatu Kajian Singkat), Cet. XV, Bandung: Refika Aditama.

[5] Jonaedi Efendi dan Johnny Ibrahim, Metode Penelitian Hukum:Nomative dan Empriris, Bandung: Prenada Media 2018.

[6] Italian Civil Procedural Code (CPC), Book III, Article. 484 and Article. 487.

[7] Code of Civil Procedure of Germany atau Zivilprozessordnung (ZPO), Article. 317 paragraf (4), Article. 699, and Article 802.

[8] LeIP (b), Laporan Studi Banding Sistem Sengketa Perdata di Italia, Jeman dan Belanda, Jakarta: Liep 2019.

[9] Direktorat Jenderal Badan Peradilan Umum, Pedoman Eksekusi Pada Pengadilan Negeri, Februari 2019.

[10] Italian Civil Procedural Code (CPC), Article. 612 and Article. 614. 